ЧУМАКОВА Анна Сергеевна - кандидат исторических наук, доцент кафедры истории Ульяновского государственного педагогического университета им. И.Н. Ульянова (432700, Россия, г. Ульяновск, пл. В.И. Ленина, 4/5; ach71@таil.ru)

\title{
КОММУНИСТИЧЕСКАЯ ПАРТИЯ В БОРЬБЕ ЗА ВОВЛЕЧЕНИЕ КРЕСТЬЯН В КООПЕРАТИВНОЕ ДВИЖЕНИЕ В 1920-х гг. (на материалах Симбирской губернии)
}

\begin{abstract}
Аннотация. Статья посвящена анализу политики большевиков в сфере политического просвещения сельского населения в 20-х гг. ХХ в. Местные (симбирские/ульяновские) органы власти проводили большую и разнообразную работу по разъяснению решений съездов и конференций Коммунистической партии, по пропаганде новой экономической политики и ее содержанию. Они раскрывали новое назначение кооперации в деле возрождения экономики страны. В результате Ульяновская губернская парторганизация достигла определенного улучшения работы кооперации и с точки зрения усиления кооперирования бедноты, и с точки зрения улучшения социального и партийного состава руководящих органов кооперации.
\end{abstract}

Ключевые слова: советская власть, сельское хозяйство, новая экономическая политика, политическая грамотность, кооперация

$\mathrm{B}$ настоящее время, когда экономика находится в кризисе, в поисках выхода мы обращаемся к историческому прошлому государства. В этой связи определенный интерес вызывает опыт кооперативного движения в СССР в 20-х гг. XX в.

Особое ценностное свойство кооперативных организаций заключается в том, что они одновременно сочетают в себе черты общественных и хозяйственных организаций, они участвуют в рыночных отношениях, позволяют преодолеть «ничейность» общественной собственности, от чего во многом страдает наша экономика, обеспечивает реальную хозяйственную самостоятельность работников, прямую связь их заработков с конечным результатом выполняемой работы.

Не случайно с первых же дней существования советская власть, провозгласившая себя властью рабочих и крестьян, обратила особое внимание на развитие аграрного вопроса и кооперативное движение. В этой работе активное участие принимала и симбирская (ульяновская) партийная организация.

На первой губернской партийной конференции, которая проходила в декабре 1918 г., в докладе И.М. Варейкиса отмечалось, что социализация земли не дала положительных результатов в развитии сельского хозяйства - необходима была национализация, общественная обработка земли в крупном масштабе. Для этого необходимо было развивать инициативу снизу, создавать трудовые сельскохозяйственные коммуны, чтобы вовлечь в них бедноту и среднее крестьянство. Отмечалась и необходимость передачи этим хозяйствам лучшей земли, инвентаря, сельскохозяйственных орудий, тягла [Лившиц 1973: 134]. На конференции было принято решение создать сельскохозяйственные коммуны. По губернии создавались хозяйственные артели, сельскохозяйственные товарищества, сельскохозяйственные кооперативы.

Широкую известность приобрела коммуна «Солидарность», созданная в селе Новая Лава Канадейской волости швейцарскими эмигрантами, среди которых было 25 коммунистов. Они привезли трактор и другую технику. Организатором 
коммуны был Фриц Платен, а идея создания такого показательного кооператива была подсказана ему В.И. Лениным [Заболотнова 1979: 119].

После Х съезда партии и перехода к новой экономической политике (нэп) перед партийной организацией встала задача полностью овладеть кооперативным аппаратом. Если в высших звеньях этой машины, в Центросоюзе, партийное влияние было обеспечено, то на местах еще предстояла борьба с буржуазными кооперативами. В своем письме «О кооперации» от 9 мая 1921 г. ЦК РКП(б) обратил внимание всех партийных организаций, что она «как по своему организационному состоянию, так и по наличности в ее составе активных коммунистических сил» далеко не везде была подготовлена к работе в условиях нэпа. В условиях военного коммунизма кооперация носила интегральный характер, т.е. все виды кооперации (потребительская, сельскохозяйственная, кустарно-промысловая) были слиты. После перехода к нэпу начался процесс дифференциации кооперации. В этих условиях было необходимо, чтобы местные органы власти проводили большую работу по разъяснению решений $\mathrm{X}$ съезда партии, по пропаганде новой экономической политики, по ее содержанию, а также чтобы они раскрывали новое назначение кооперации в возрождении экономики страны.

Так, Симбирский губернский комитет (губком) партии на своем заседании 27 марта 1921 г. разработал мероприятия по разъяснению среди трудящихся решений Х съезда РКП(б). Вслед за тем совещание партийно-советского актива признало необходимость послать в волости 500 коммунистов для оказания непосредственной помощи сельским парторганизациям по широкому разъяснению нэпа.

Необходимость таких мероприятий была вызвана тем, что на местах не хватало политически грамотных кадров, а в сельских парторганизациях значительная часть членов имели низкий общеобразовательный уровень. Поэтому не только для рядовых коммунистов, но и ряда руководителей сущность нэпа была непонятной. Во всех уездах были проведены совещания секретарей волостных комитетов (волкомы) партии, а в волостях - секретарей партийных ячеек, в ходе которых всесторонне обсуждались конкретные задачи, вытекающие из решений съезда о продналоге. Также широкий размах получили такие формы массово-разъяснительной работы, как конференции и собрания рабочих и крестьян. Только в апреле-мае 1921 г. в деревнях и на промышленных предприятиях состоялись 427 собраний по вопросам нэпа. Губком и уездный комитет (уком) партии на весь период весеннего сева направил из городов 526 коммунистов в помощь сельсоветам и деревенским партийным ячейкам. Они провели свыше 300 крестьянских митингов и собраний, около 100 лекций и докладов по вопросам нэпа и весенней посевной кампании [Заболотнова 1979: 121].

Однако, работая над политической грамотностью крестьян, партийные организации не забывали и о своей подготовке. В Симбирской губернии в 1921 г. были открыты 8 советских партийных школ, где одновременно обучались около 600 чел. [Зайцева, Фарафонтова 1989: 9]. Они играли важную роль в подготовке и переподготовке партийных кадров для уездного и волостного звена.

Для кооперативов были организованы курсы по различным направлениям их деятельности. Состоявшаяся 3-4 июня 1922 г. 8-я уездная партийная конференция подчеркивала необходимость укрепления партийных ячеек в условиях нэпа. Так, отмечалось, что каждый коммунист должен научиться хозяйствовать, проявлять инициативу в кооперативном движении. Постановлением оргбюро Симбирского губкома РКП(б) от 11 сентября 1922 г. была создана кооперативная комиссия «для направления работы всех видов кооперации» [Зайцева, Фарафонтова 1989: 13] и выполнения резолюций 8-й уездной конференции. 
На 10-й губернской конференции от 25-29 июля 1922 г. одним из обсуждаемых вопросов был вопрос о строительстве кооперации. Конференция поставила задачу укрепить кооперацию путем экономической заинтересованности. Льготы давались только тем, кто сделал паевые и целевые взносы. Через полгода на 11-й партконференции в резолюции вновь подчеркивалась необходимость через партийную фракцию оказать влияние на ход кооперирования в губернии, придать этой работе системный характер.

Добиваясь восстановления сельского хозяйства и укрепления смычки между городом и деревней, партия уделяла огромное внимание работе в деревне, проводила в своей политике классовою линию, имевшую конечной целью социалистическое преобразование мелкого индивидуального крестьянского хозяйства.

В 1923 г. губком партии направил всем укомам РКП(б) письмо, в котором подчеркивалось значение кооперации в ликвидации частной капиталистической торговли, в укреплении союза рабочих и крестьян, в улучшении их быта, в развитии народного хозяйства. В письме указывалось, что кооперация есть наиболее простой, легкий и доступный для крестьян путь перехода к лучшей жизни.

Губком партии призывал всех членов партии осознать колоссальное значение кооперации, вести работу на местах, развивая широкую агитацию делом. Каждый коммунист должен был стать пайщиком.

В конце 1923 г. губком партии рекомендовал укомам РКП(б) в связи с усиливавшимся классовым расслоением крестьянства уделять особое внимание крестьянским кассам взаимопомощи, которые являются организациями всего крестьянства. Материальные ресурсы и средства они брали у материально обеспеченных слоев крестьянства (середняцких и более зажиточных). В их правлениях обязательно должны были работать демобилизованные красноармейцы, 1-2 партийца, трудовое крестьянство. В Симбирской губернии было 193 сельские кассы взаимопомощи. Они имели в своем распоряжении 14 мельниц, 1 кирпичный завод, прокатные пункты инвентаря [Лившиц 1973: 113].

Пример подбора состава правления касс взаимопомощи показывает, как строго соблюдался принцип классового подхода. То же самое происходило и при комплектовании комиссий по земельным спорам, где подчас юридическая подготовка управленцев была равна нулю, и при восстановлении в 1923 г. агрономической службы. Именно по этой причине эти органы не могли в должной мере выполнять свои функции. На состоявшемся в мае 1924 г. ХIII съезде партии одним из основных вопросов был вопрос о нэпе. В резолюции «О работе в деревне» отмечалось, что в хозяйственном развитии деревни к концу восстановительного периода наметились две линии. Первая линия - развитие капитализма в деревне. Она бы привела к разорению части крестьянства и созданию капиталистических предприятий в сельском хозяйстве. Политически это означало бы гибель советской власти. Вторая линия - развитие социализма в деревне через наиболее понятные, легкие и доступные крестьянству приемы кооперации. В решениях ХІІІ съезда подчеркивалось: «Переход к нэпу “удесятеряет значение кооперации", только кооперирование крестьянства позволит добиться увеличения производства маломощных слоев деревни и покончить с кулацкой эксплуатацией» [Лившиц 1973: 117]. Съезд высказался за поддержку различных форм кооперации, начиная от самых простейших, но вместе с тем предупреждал, что условия для массового кооперирования крестьян еще не созрели, что для этого потребуется ряд лет.

Октябрьский пленум ЦК РКП(б) 1924 г., обсуждавший вопрос об очередных задачах работы партии в деревне, поставил перед партийными организациями 
задачу направить политическую активность крестьянства на оживление работы Советов и других общественных организаций в деревне. Пленум указывал, что эта задача является одной из основных и наиболее острых задач момента. В работе сельских советов и в практике их перевыборов были серьезные недостатки. Администрирование, сохранение методов навязывания крестьянам обязательных кандидатур в Советы находились в противоречии с новыми условиями, сложившимися в деревне.

Местные партийные организации развернули огромную работу по осуществлению решений Октябрьского пленума ЦК РКП(б) 1924 г., выдвинувшего лозунг: «Лицом к деревне!». Повсеместно проводились беспартийные конференции, совещания крестьян, результаты которых внимательно изучались партийными комитетами. Из губернских центров на 1-2 месяца направлялись ответственные работники для практической деятельности по улучшению работы деревенских партийных ячеек и Советов. Так, Ульяновский губком партии до марта 1925 г. выдвинул 24 чел. [Зайцева, Фарафонтова 1989: 18].

Многие коммунисты, делегированные в деревню из городов, стали председателями колхозов, директорами совхозов, вели работу в уездных и волостных комитетах. В марте-мае 1925 г. для работы в деревню были направлены уже 37 чел. [Зайцева, Фарафонтова 1989: 19].

Для подготовки сельских специалистов были открыты специальные школы и техникумы (например, Скугареевская и Промзинская сельскохозяйственные школы, Ульяновская школа специалистов сельскохозяйственной отрасли) [Филимонова 1958: 166]. В целях обучения крестьян научному ведению земледелия в губернии работали курсы по переподготовке агрономов, землеустроителей, сельскохозяйственные курсы для населения. Были организованы две сельскохозяйственные выставки, которые пропагандировали передовые методы ведения хозяйства.

В январе 1925 г. при губкоме партии была создана деревенская комиссия под председательством ответственного секретаря РКП(б) А.В. Попова. Главная цель комиссии - укрепление влияния партии в кооперативных организациях. Так, пролетариат Симбирска, реализуя лозунг: «Лицом к деревне!», взял шефство над 7 селами и деревнями Заволжья. Только за 3 месяца 1925 г. эти рабочие (для этого было специально создано Добровольное общество культурного шефства над деревней) осуществили 44 выезда в подшефные села [Филимонова 1958: 167]. Рабочие интересовались всеми сторонами жизни подшефных сел, проводили агитационную и справочную работу.

Новое отношение к землеустройству началось с апрельского 1925 г. пленума ЦК РКП(б), который признал одной из главных задач содействие «росту таких форм землепользования, которые более благоприятны для развития кооперирования и механизации сельского хозяйства» [Кабанов 1993: 44]. Новое отношение было вызвано дискуссиями о строительстве социализма и желании противостоять росту деревенской буржуазии путем создания «социалистических командных высот» в деревне. Вновь обсуждался вопрос об организации коллективных хозяйств. ЦК РКП(б) признал недопустимым невнимательное отношение со стороны советских и партийных органов к совхозам и потребовал принятия мер по их укреплению. 9 февраля 1925 г. было принято постановление «О совхозах», где им отводилась главная роль в реконструкции сельского хозяйства. А 6 марта 1925 г. СНК РСФСР принял постановление «О мероприятиях по укреплению экономического положения сельских хозяйств» [Кабанов 1993: 44]. Вновь началось преимущественное землеустройство колхозов и совхозов.

В этих новых условиях в июле 1926 г. пленум Ульяновского губкома партии констатировал, что работа сельскохозяйственной и кредитной кооперации слаба 
и не отвечает задачам социалистического строительства. Усиливая партийное и советское руководство этими видами кооперации, губком партии предпринял в течение 1926-1927 гг. ряд обследований состояния сельскохозяйственной кооперации (они были проведены губернской контрольной комиссией РКИ, губернским земельным управлением). Были выявлены недостатки в работе партии в сельскохозяйственной кооперации. Некоторые коммунисты, возглавлявшие сельхозкооперацию, увлекались коммерческой работой в ущерб хозяйственно-организационной массовой работе. Партийные организации систематически в течение ряда лет обращали внимание кооперативных работников на необходимость широкого привлечения средств населения в кооперацию и сокращения административных расходов. В отчете Ульяновского губкома партии на 14-й губернской конференции, с которым выступил Ф.И. Верестенов, был дан глубокий анализ товарооборота в губернии. Докладчик показал, что вследствие существования излишних звеньев в товаропроизводящей сети накидки на цены в низовой сети кооперации на ситец, кровельное железо, оконное стекло составляли 25-66\% по сравнению с государственными розничными ценами [Лившиц 1973: 103]. В принятой по докладу губкома резолюции конференции было записано, что одной из центральных задач партийной организации является «вопрос режима экономии, снижения розничных цен, борьба с растратами, бюрократизмом, волокитой».

Также в 1926 г. было осуществлено 17 выездов караульной роты г. Сызрани в подшефные села с целью политического и культурного просвещения крестьянства, ознакомления его с политикой советской власти.

Собравшаяся в ноябре 1927 г. 17-я губернская партийная конференция отметила перелом к лучшему в деятельности сельскохозяйственной кооперации. Была отмечена тенденция к постоянному росту всех видов кооперативов, возникновению новых кооперативов, укреплению финансового положения кооперации. Укомы и волкомы партии стали более конкретно подходить к руководству делом кооперирования сельского хозяйства в своих районах.

Увеличилось представительство РКП(б) в правлениях низовых сельхозкооперативов. Если в 1926 г. в составе тех же правлений число коммунистов составляло только 22\%, то в 1927 г. - уже 32,6\%1. Состав правлений потребкооперативов в 1927 г. также изменился: произошло увеличение числа коммунистов в правлениях с 13\% до 17,2\% [Филимонова 1958: 175].

В результате ко времени XV съезда партии Ульяновская губернская парторганизация достигла определенного улучшения работы кооперации и с точки зрения усиления кооперирования бедноты, и с точки зрения улучшения социального и партийного состава руководящих органов кооперации.

В декабре 1927 г. состоялся XV съезд РКП(б), вошедший в историю как съезд коллективизации. Ульяновцев на этом съезде представляли Ф.И. Верестенов, А.Н. Горбунов, В.Н. Макарищев и Н.В. Яковлев. На съезде речь шла о постепенном переходе к коллективной обработке земли на основе новой техники. Ни сроки, ни, тем более, единственные формы и способы кооперирования крестьянских хозяйств съезд не устанавливал.

На состоявшемся 27 декабря 1927 г. собрании городского партактива, посвященного итогам съезда, подчеркивалось: «Для Ульяновской губернии как сельскохозяйственной особую важность представляют решения съезда о работе в деревне. Партийный съезд впервые и с особой четкостью поставил задачу производственной коллективизации, обобществления крестьянского хозяйства. Эта серьезная и трудная задача требует от партийных организаций и советских

\footnotetext{
${ }^{1}$ Государственный архив Ульяновской области (ГАУО). Ф. 316. Оп. 1. Д. 104. Л. 87.
} 
органов улучшения качества работы» ${ }^{1}$. Разъясняя решения съезда крестьянству, сельские партийные ячейки провели весной 1928 г. 5046 собраний [Зайцева, Фарафонтова 1989: 24].

Подводя итог, следует отметить, что главным, чего добилась парторганизация, работая в кооперации, было то, что широкие массы середняков и бедноты все более убеждались в выгодах и преимуществах кооперирования. Они пошли в кооперативы, т.к. именно в них они видели средства подъема своего хозяйства в новых, социалистических условиях.

\title{
Список литературы
}

Заболотнова М.И. 1979. Массово-политическая работа симбирских коммунистов по разъяснению постановлений 10 съезда РКП(б) о переходе к нэпу. История партийных организаций Поволжья: межвузовский научный сборник. Вып 9. Саратов: Изд-во СГУ. С. 115-122.

Зайцева Т.И., Фарафонтова В.С. 1989. Кооперация родного края Ильича в двадиатых годах. Ульяновск: Обл. совет профсоюзов, Парт. архив Ульяновской обл. $48 \mathrm{c.}$

Кабанов В.В. 1993. Пути и бездорожье аграрного развития России в XX веке. - Вопросы истории. № 2. С. 34-46.

Лившиц А.Э. 1973. Деятельность партийных организаций Поволжья по осуществлению ленинских принципов кооперирования в годы восстановительного периода. Саратов: Изд-во СГУ. 192 с.

Филимонова А.В. 1958. Борьба за предпосылки коллективизации сельского хозяйства в Ульяновской губернии ко времени 15 съезда партии. - Краеведческие записки. Вып. 2. Ульяновск. С. 159-183.

\section{THE COMMUNIST PARTY IN THE STRUGGLE FOR THE INVOLVEMENT OF PEASANTS IN THE COOPERATIVE MOVEMENT IN THE 1920s (on the materials of Simbirsk Province)}

\begin{abstract}
The article is devoted to the analysis of the policy of Bolsheviks in the sphere of political education of the rural population in the 1920s. Local (Simbirsk/Ulyanovsk) authorities carried out a large and varied work on explanation the decisions of the congresses and conferences of the Communist Party, on promotion of the new economic policy, its content. They revealed the new purpose of cooperation in revival of the national economy. As a result, the Ulyanovsk provincial Communist Party organization reached a certain improvement in the work of cooperation and in terms of strengthening cooperation of the poor, and in terms of improvement of social and party composition of the governing bodies of cooperation. Keywords: Soviet power, agriculture, new economic policy, political literacy, cooperation
\end{abstract}

1 Пролетарский путь. 1927. 28 декабря. 